\author{
JUHÁSZ PÉTER \\ p.juhasz2003.gmail.com \\ PhD-hallható (SZTE BTK)
}

\title{
A honfoglalók létszámának kérdéséhez
}

\author{
OAPO \\ - Population of a Hungarian tribes in the 9th. century -
}

Abstract The number of the conquering Hungarians is a long debated issue in the Hungarian historical research The main source of calculations is based upon the so-called Muslim Ğayhānī-tradition (Ibn Rusta, Gardizi) which states that the Hungarian king (k.n.de-kündü) rode out with 20.000 horsemen. Besides this, the medieval Hungarian conscriptions and the number of graves from the age of the Hungarian conquest of the Carpathian Basin constitute a rather small source-basis of these demographical hypotheses. Some scholars supposed that the number of the population of the conquering Hungarian and Qabar tribes was about 400.000-500.000. Other scholars calculated a much smaller Hungarian population about 100.000. It has been even assumed that the number of Hungarians was not more than 14.000. It was debated whether the army of the Hungarians could have been 20.000 ( 2 tumens), or it was much smaller. All these calculations depend on the economy and way of life of the conquering Hungarians in the 9-10 centuries (nomad or semi-nomad). According to the author of the study, we can estimate the Hungarian army at about 14.000-20.000 and if we accept their nomadic way of life and multiple their number with $5-6$, we can estimate their numbers $30.000-100.000$, which seems to be a realistic judging.

Keywords population, Hungarian tribes, $9^{\text {th }}$ century

DOI 10.14232/belv.2015.3.7

http://dx.doi.org/10.14232/belv.2015.3.7

Cikkre való hivatkozás / How to cite this article:

Juhász Péter (2015): A honfoglalók létszámának kérdéséhez. Belvedere Meridionale 27. évf. 3. sz. 66-76. pp

ISSN 1419-0222 (print) ISSN 2064-5929 (online, pdf)

(Creative Commons) Nevezd meg! - Így add tovább! 4.0 (CC BY-SA 4.0)

(Creative Commons) Attribution-ShareAlike 4.0 International (CC BY-SA 4.0) 
Az alábbi tanulmányban arra a fontos kérdésre keresek választ, hogy mekkora lehetett a honfoglaló magyar és kavar törzsek népességének létszáma. Elöször a történeti kutatásban felmerült hipotéziseket, becsléseket tekintem át, és ezeket is felhasználva fogalmazom meg saját feltevésemet ebben a nemcsak demográfiai szempontból fontos kérdéskörben.

A honfoglalók létszámának a szakirodalomból ismert becsléseit alapvetően az egyes szerzőknek a magyarság életmódjával kapcsolatos felfogása határozza meg, tekintettel arra, hogy írott forrásaink e tekintetben nem adnak biztos felvilágosítást. A kutatók jellemzően két eljárást követtek. Egyesek a 9. század utolsó harmadára (870-880 körülre) - tett muszlim forrásadatból indultak ki, amely 20 ezer lovasban határozta meg a magyarság haderejét. A Dzsajhánihagyományt (Ibn Ruszta, Gardízi stb.) képviselő híradás szerint „fönökük 20 ezer lovassal vonul ki." " Mások pedig későbbi, középkori adatokból visszakövetkeztetve igyekeztek megállapítani a honfoglalók és a helyben találtak létszámát.

Pauler Gyula úgy vélekedett, hogy a 9. századi magyarság Levediában élve mintegy 100 ezer főt számlálhatott családostul. Pauler az Ibn Rusta munkájában szereplő 20 ezer lovasból álló magyar haderőből indult ki, Danilevszkynek és Grigorjevnek a nomád népek feltehető létszámáról leírt megállapításai is felhasználva. Pauler 5 fős családokkal, és minden családból egy harcossal számolhatott. ${ }^{2}$

Molnár Erik a 15. század végi Magyarország lakosságszámát 3,4 millióra tette, és ebből számolt visszafelé, századonként ${ }^{1} / 6$ növekedéssel számolva. Így a 13 . század végére mintegy 2,5 millió fős, a 11. század végére 1,8 millió, a 10. század végére 1,5 millió, a honfoglalás időpontjára 1,35 milliós népességet állapított meg. ${ }^{3}$

Elsőként Györffy György vizsgálta részletesen Magyarország népesedési viszonyait a teljes Árpád-kori időszakot tekintve. A kora Árpád-kor, a 11-13. század népességét néhány ismert területü település népsürüségi adatai, egykorú jövedelmi összeírások, valamint a 14. század eleji pápai tizedjegyzék alapján kísérelte meghatározni. Olyan jelentős népességpusztulást tételezett fel a tatárjárás következében, hogy elképzelése szerint a 13. század végén, a 14. század elején még mindig a 12. század végi 1,8-2,2 milliós lakosságszámmal bírt Magyarország, tehát a népesség stagnálását tételezte fel. A 11. században egymilliós, a honfoglalás időpontjában pedig mintegy 600 ezer fős népességgel számolt, amelyből 400 ezer a honfoglalók, 200 ezer pedig a helyben találtak létszáma lenne. A honfoglalók létszámát oly módon állapította meg, hogy a Dzsajhánihagyomány 20 ezer magyar lovasról szóló adatát csak a nemzetségfök lovas katonai kíséretének értelmezte, és a 17. századi székely állapotok alapján állapította meg a lovas katonai kíséret és a köznép 1:4, 1:4,5 körüli arányát. Ezt az arányt használva a lovas kíséret 20 ezer családjához a köznép 80 ezer családját hozzáadva jutott el a 100 ezer etelközi magyar családhoz, majd ezt a besenyő támadás és egyéb veszteségek miatt 20 ezerrel csökkentve a 400 ezer főnyi honfoglalóhoz. ${ }^{4}$

Györffy a bizánci történetíró, Kinnamos 12 . századi adatát is felhasználta, amely szerint 50 vármegye egyenként 400 főt adott a magyar haderőbe. ${ }^{5}$ Mivel Györffy a vármegyéket a 10. századi magyar nemzetségekre vezette vissza, a 20 ezer harcost a hét magyar és a három kavar törzs 50 nemzetsége által adott 400-400 katonával hozta összefüggésbe, a 10. századi nyolc besenyő törzs

\footnotetext{
1 Ibn Ruszta híradására MEH 86.; HKÍF 32.; más fordítással Kмoskó 1997. 207.; Zıмonyi 2005. 35.

2 Pauler 1899. II. 373-374. 5. jegyzet

3 Molnár 1949. 248-249.

4 Györffy 1963. 45-62.

5 Moravcsik 1984. 29.
} 
ismert számú, 40 nemzetsége segítségével következtetve a törzsek és nemzetségek arányára. ${ }^{6}$

Bartha Antal a honfoglalás kori magyarság lélekszámát a Dzsajháni-hagyomány említett adata alapján határozta meg, amely szerint a magyaroknak 20000 lovasa volt. Elfogadta azt az álláspontot, amely szerint 1 felfegyverzett harcos kiállítása 4-5 család anyagi erejéből tellett ki. Ennek alapján kb. 100000 családdal, összesen 500000 főnyi népességgel számolt, mely számból a nem teljes családokat, és az etelközi és bulgáriai veszteségeket leszámítva mintegy 400000 450000 honfoglalót feltételezett. Ehhez járultak hozzá a Kárpát-medencében talált szláv és avar töredékek, amelyekkel az összlétszám 600000 főnyire bővülhetett. ${ }^{7}$

Moór Elemér vitatta Bartha álláspontját a honfoglaló magyarság 400-500 ezer fős létszámáról, amellyel Bartha Moórnak a szláv földmüvelés és állattenyésztés felső-Tisza-vidéki magyar átvételéről alkotott hipotézisét kívánta megkérdőjelezni, a tárgyalt területnek ekkora népesség számára túlzottan kis méreteit hangsúlyozva. Moór azonban felhívta arra a figyelmet, hogy Hómannal szemben, aki hasonló létszámot tételezett fel, szerinte „nagyzoló, romantikus” módon, az egykorú keleti forrásokra hivatkozó Erdélyi László 160-200 ezer főnyi, Bartucz pedig 100 ezer fö körüli honfoglalóval számolt. Moór úgy vélekedett, hogy az ekkortájt készülőben levő Szőke Béla-féle leletkataszter adatainak kiértékelése még alacsonyabb létszámot fog valószínűsíteni. ${ }^{8}$

Fügedi Erik a honfoglalók létszámát - Györffy György számításait elfogadva, és a 9. századi magyar haderő húsz ezres létszáma alapján -, a nomád népeknél egy lovasra számítandó 25 ember alapján kapott 500 ezer, a veszteségek figyelembe vételével 450 ezer före becsülte. Fügedi elfogadta az avar kori népesség 9. századi tömeges pusztulását valló nézetet is, és a helyben talált lakosságot 200 ezer före számította. Szembetalálkozott azonban azzal a nehézséggel, hogy a későbbi adatok alapján ez az összesen 600 ezres népesség az államalapítás idején, 1000 körül már egy milliós létszámú lehetett. Ezért nagy tömegű bevándorlással kalkulált, méghozzá, figyelembe véve a magyarság merev elzárkózását nyugat felé; besenyő, dunai bolgár, és izmaelita beköltözéssel számolt. Az embertani adatok alapján meghatározott négy ezrelékes magyarországi népességnövekedést feltételezve, 250 év kellett volna a népesség megduplázásához, azonban az így adódó 1350 körüli két milliós lélekszámot már jóval korábban elérte a népesség. Fügedi újból nagyarányú bevándorlással magyarázta e jelenséget; francia, vallon, flamand, szász betelepüléssel számolva. Érdekes, hogy a legnagyobb számban betelepülő szlávokra viszont egyáltalán nem gondolt. Az 1526-ig szerinte négy milliónyira nőtt népesség mintegy $80 \%$-a magyar anyanyelvü volt, a nagyarányú bevándorlás ellenére. ${ }^{9}$

Tóth Sándor László arra hívta fel a figyelmet, hogy a Dzsajháni-hagyomány (Gardizi) szerint a bolgárok a magyaroknál gyengébbek voltak, viszont a besenyők mindenképpen többen lehettek a magyaroknál, ezt forrásaink (Regino, Gábriel klerikosz) egyértelmüen megírták. A magyar törzsek minden valószínűség szerint már ekkor is egységesen léptek fel külső támadás esetén, akár csak a 10. század közepén, így nem valószínű az sem, hogy csak néhány magyar törzs részvétele indokolná a besenyőktől elszenvedett etelközi vereséget. Még a 10. század első fele táján is elevenen élt a vereség emléke, amit Gábriel klerikosz tudósítása őrzött meg számunkra. ${ }^{10}$ Tóth hangsúlyozta azt, hogy a források alapján a besenyő csapás mindenképpen katasztrofális volt, ennek cáfolataként nem fogadta el a régészek álláspontját arról, hogy a honfoglalás kori

\footnotetext{
6 GYöRfFY 1977. 17., 450.

7 BARTHA 1968. 149.

8 Moór 1974. 173-18.1, 178-179.

9 Fügedi 1984. 289-295.

10 То́тн 1988. 566-568.
} 
magyar temetőkben nincsen nyoma nem magyar családtagok tömeges jelenlétének, ami a családok súlyos veszteségeiről szóló híradás hitelességét megkérdőjelezhetné. ${ }^{11}$ Más munkájában toposzszerủ adatnak minősítette a muszlim forrásokban szereplő 20 ezres magyar haderőt, de nem utasította el ennek hitelességét. ${ }^{12}$

Kristó Gyula a muszlim források 20 ezres magyar haderejéről szóló adatot csak a csatlakozott népek haderejének beszámításával fogadta el, tekintve azt, hogy a kazárok saját hadereje 10 ezer, illetve 12 ezer fö volt mindössze. Figyelmeztetett a kora középkori népességekre, illetve haderőre vonatkozó számadatok szélsőséges határok közötti mozgására, bizonytalanságára is. Emellett a haderőből a népesség számának meghatározásához használt szorzószám problémáira is felhívta a figyelmet. Becslése szerint 20 ezres haderő kiállításához legalább 200 ezres népesség volt szükséges, azonban 500 ezres népességhez mérve túl kevésnek tünik e katonai létszám. Úgy vélte, hogy maga a magyar haderő 14 ezer fő körüli lehetett, és a csatlakozott népekével együtt érhette el a 20 ezret. A nomád honfoglaló magyarság lehetséges legnagyobb létszámát 100 ezer före tette, egy 6. századi nomád népre vonatkozó adat alapján 6-os szorzóval számolva, 20 ezer főben határozva meg a honfoglalás áldozatainak számát. ${ }^{13}$ Kristó az embertani adatok alapján hangsúlyozva a helyben találtak jelentőségét, azok létszámát „roppant hipotetikus becslés” alapján 150-250 ezer före tette. ${ }^{14} \mathrm{~A} 11$. századi népességet $500-550$ ezer, ${ }^{15}$ a 12 . század végi népességet egymillió, ${ }^{16}$ a 13. századi népességet pedig körülbelül másfél millió főben állapította meg. ${ }^{17}$

Makkay János felhívta a figyelmet a korabeli források túlzásaira a létszámadatok tekintetében. Makkay ezen kívül azon az alapon vitatta a 400 ezer honfoglalóról szóló hipotézist, hogy ebben az esetben négy generáció alatt (895-997) nemzetségi temetők tömegével, egy-egy nemzetség területén 40 ezer sírral kellene számolnunk, hozzájuk számítva a helyi lakosság sírjait is. Ennyi honfoglaló sírra számítani naívság lenne. ${ }^{18}$ Makkay hivatkozott Regino adatára, amely szerint a besenyők számban felülmúlták a magyarokat, valamint arra az adatra, hogy 1040-ben két besenyő törzs, mintegy 20 ezer ember vált ki a besenyők közül. Egy besenyő törzs tehát vélhetően 10 ezer főből állhatott. A türk támadás hatására 552-ben nyugatra vonult avarok száma körülbelül 20 ezer lehetett, egykorú forrás szerint. A régészet a korai avarság összlétszámát ugyanakkor jóval 100 ezer fölé tette. Makkay mindennek alapján a honfoglalók létszámát 100 ezer fö környékére becsülte. ${ }^{19}$

Vékony Gábor Paulerre és Vámbéryra hivatkozva bizonytalan adatként értékelte a 9. századi magyar haderő 20 ezres létszámát, emellett a Dzsajháni-hagyomány adatainak bizonytalan datálását figyelembe véve inkább a 920-as évekre vonatkoztatta. Szerinte ekkor már a magyar haderőhöz a helyi morvákat és bolgárokat is adatoltan hozzá kell számolnunk, tehát a 9. századi magyar haderő és népesség nem következtethető ki ebből az adatból. ${ }^{20}$ Ennek alátámasztása céljából Vékony Harūn ibn Yahyā 913 utánra keltezhető útleírására hivatkozik, amelyet Peter B. Golden vonatkoztatott a langobardok helyett a magyarokra. Ebből kiderül, hogy azok pusztasá-

\footnotetext{
11 Tótн 1988. 570.

12 То́тн 2010. 218.

13 Kristó 1995. 44-46.; KRISTó 1996. 112-114.

14 KRIsTó 1995. 47-49.; KRISTó 1996. 114-117.

15 KRIstó 1995, 57; KRIstó 1996. 129.

16 KRISTó 1995. 77.; KRISTó 1996. 142.

17 KRIstó 1995. 84.; KRISTó 1996. 148.

18 Makkay 1994. 45-46.

19 Makkay 1994. 46-47.

20 VÉKony 2001. 85-86.
} 
gaikat, amelyeknek együtt áradó folyópárja van, kevés idővel azelőtt szállták meg. Területük húsz „dzswTh”-ra oszlik. Vékony szerint, ahogy a szövegben a magyarok neveként használt „ongúríní” neolatin, olaszos forma, úgy e területmérték ugyanígy olasz eredetű lehet, méghozzá a „civita” szó korrekt arab fordítása. E húsz területi egység szerint szoros összefüggésben van a húszezer magyar lovassal, a magyarok kárpát-medencei területi egységeinek seregei adhatták az alapot ehhez a létszámhoz. Mivel azonban egy-egy megye az Árpád-korban legfeljebb 400 katonát tudott kiállítani, a valóságban aligha lehetett a 10. századi haderő 20 ezres. ${ }^{21}$ Vékony későbbi adatokból való visszaszámolással kísérelt meg reálisabb eredményre jutni. Legkorábbi erre alkalmas adatsor az 1495. évi adóösszeírás. Kubinyi András ennek felhasználásával a népességet minimálisan 2911 190-re, maximálisan 3307225 före tette. ${ }^{22}$ Vékony arra is figyelmeztetett, hogy szemben a magyar kutatásban használt 0,4\%-al, a valóságban a különböző európai területeken végzett számítások nyomán 0,2\%-re tehető a maximális természetes szaporodás a középkorban. Ennek figyelembe vételével ellenőrizte a Györffy által 600 ezresre becsült 900 körüli, honfoglalás kori népességszámot. Ebből kiindulva 1754030 fő adódik 1370-re, ami a népességszám ismert 15. századi stagnálását figyelembe véve a század végére is mérvadó. Ez az adat több mint 1 millióval kisebb a valóságos számnál, tehát a 600 ezres lélekszám valótlan. Vékony nézete szerint a fentiek miatt nem fogadható el a Kristó által feltételezett 100 ezer főnyi honfoglaló és 150-250 ezer helyi lakos, hiszen 900 körül legalább 1 milliós összlakosságnak kellett lennie. Vékony Kubinyi 1495-ös minimális népességszámából számolt vissza, a tatárjárás, és a honfoglalás idejére egyaránt 15\%os, a 9. századra 20\%-os veszteséggel számolva. Eredményeként 800-ra 1439 750, a honfoglalás után 1195300 népességet kapott. Számításait más adatokkal is módosította, illetve ellenőrizte. Ilyen információ például a székelyek lélekszáma az 1332-37-es pápai tizedlajstrom alapján, Abu-Hāmid al-Garnatī nagyságrendi párhuzama a 78 magyar vármegye és az ismert lakosságú muszlim városok között, Freisingi Ottó adata a vármegyei haderőben részvett falusiak számarányáról, valamint a csekély számú népsürüségi információk. ${ }^{23} \mathrm{Az}$ így nyert adatok azonban irreálisan magas népességszámot adnak az avar kor végére, az avar kori temetők használatának 568-800 közé tett időtartama, az ismert sírszámok, az éves halálozás és a sírok feltártsági aránya alapján. Ha azonban elfogadjuk Kralovánszky Alán álláspontját az avar temetők 10. századig történt használatáról, és a legújabb dendrokronológiai adatokat, így négy évszázadra terjesztjük ki azok használati idejét (568-968), akkor kapjuk meg a visszaszámolt adatokkal egyeztethető népességszámokat. ${ }^{24}$ Vékony az első generációsnak tekinthető 222 klasszikus honfoglaló sír alapján, 33 éves generációtávolsággal számolva, 30\%o-es halálozási aránnyal - az Árpád-kori temetőkre kiszámított feltártsági mutatót figyelembe véve - mintegy 86 ezer főnyi honfoglalóra következtetett. Párhuzamként használva a betelepülő nomád kunok létszámát - Pálóczi-Horváth Andrással szemben, aki 65-85 ezer kunnal számolt -, visszaszámlálással mindössze 12-14 ezer főben határozta meg. Pálóczi magas számadata szerinte abból adódott, hogy a nomádokra jellemző max. 2 fö $/ \mathrm{km}^{2}$ helyett a magyarországi 13. századi népsűrűséggel számolt. A kunok valós számához képest tehát a 86 ezer honfoglaló magyar óriási szám. Vékony a klasszikus honfoglaló síroknak az Árpád-kori sírokhoz képest közismerten sokkal nagyobb feltártsági mutatójával módosítva számítását, 14 ezer fős, tehát a beköltöző kunokéhoz hasonló létszámú honfoglaló magyarságot mutatott ki. Vékony szerint a Brenta folyónál Berengár ellen harcoló

\footnotetext{
21 VÉKONY 2001. 85-86.

22 VÉKONY 2001. 87.

23 VÉKONY 2001. 87-95.

24 VÉkony 2001. 97-98.
} 
mintegy 5 ezer fő körüli magyar haderő a teljes magyar haderő lehetett, amit Piligrim passaui püspöknek 5 ezer magyar férfit és nőt a magyarság jelentős részének mondó adata is megerősít. Vékony felhívta arra a figyelmet, hogy ezek szerint a Kárpát-medence 900 körüli lakosságának csak mintegy 1\%-át teszi ki a honfoglaló magyarság. Szerinte tehát a későbbről ismert etnikai viszonyok nem magyarázhatóak a honfoglalás következményeként. ${ }^{25}$

Zimonyi István 2005-ös munkájában úgy vélekedett, hogy a muszlim földrajzi irodalom áttekintése azt bizonyítja, hogy az abban szereplő létszámadatok reálisak, ilyenek például a kínai, illetve a bizánci haderő létszámára vonatkozó adatok. A magyarok 20 ezer harcosa a korabeli sztyeppei és szomszédos népek haderejével összehasonlítva szintén reálisnak tünik. Ez a haderő a korabeli nomád hadszervezetben két tümennek (vö. magyar tömény szavunk), tízezrednek felelt meg, tehát kétszer tízezer harcosról van szó. Azonban arra nézve, hogy a tümen a valóságban hány főből állhatott, legkorábban a 13. századból, a mongol korból származnak adatok. Ekkor a kínai források szerint a nagy tümen 7 ezer föből, a közepes 5 ezerből, a kis tümen pedig 3 ezer emberből állt. A ritkábban lakott Tibetben ugyanakkor egy tümen átlagosan 2818 főből állt. Zimonyi arra is figyelmeztet, hogy ebből a lakosság számát különböző szorzókkal lehet kiszámítani, attól függően, hogy milyen társadalmi feltételekkel számolunk. ${ }^{26}$

Amint a fenti szakirodalmi áttekintésből is kitűnik, a 9. századi magyarság létszámára nézve a 20 ezer fős haderőről szóló muszlim forrásadat szinte minden kutatónál kiindulási pontnak számít. Többen azonban a kora középkori források létszámadatainak erősen eltúlzott voltára figyelmeztettek. A Zimonyi István által végzett részletes vizsgálat ugyan egyes esetekben megbízhatónak mutatta a számadatokat, azonban a pontos számokat hozó források keletkezésük egyedi körülményei következtében rendelkeznek csupán korrekt információkkal. A Kínára vonatkozó adatok a kínai birodalom hatalmas népessége és magas fokú szervezettsége miatt látszanak elfogadhatónak, a Bizáncra vonatkozóak pedig muszlim hadifogolytól származnak. Ezzel szemben a nomádokkal kapcsolatos számadatok igen szélsőséges skálán mozognak, erre Zimonyi és Makkay is felhívta a figyelmet. Következésképpen a 20 ezres szám aligha lehet pontos. ${ }^{27}$

Zimonyi István arra is figyelmeztetett, hogy néhány ezer fös nomád hadsereg már igen komoly haderőnek számított. Igen érdekes, hogy míg a korabeli kínai adatok 10 ezer és 400 ezer fő közé teszik a türk haderőt, magukban a türk feliratokban a kínaiak és más népek ellen harcoló türk csapatok létszáma mindössze néhányszáz vagy néhány ezer fö. ${ }^{28}$ Egy támadó ujgur haderőt a kínaiak 100 ezer fősre becsültek, de a felderítők kiderítették, hogy mindössze 4 ezer fös hadseregről, 10 ezer családtagról és 40 ezer lóról van szó. ${ }^{29}$ Utóbbi híradás azért fontos, mert Bölcs Leótól tudjuk, hogy a magyarokat is nagy csapat ló követte a harcban, éppen a sokaság látszatát keltendö. ${ }^{30}$ A magyarok 899-900-ban Itáliában harcolva egy válságos helyzetben, a brentai csata (899. szeptember 24) előtt lovaik átadását ígérték Berengár csapatainak, elengedésük fejében, úgy, hogy mindegyik harcos csak egyet tart meg. ${ }^{31}$ A nagyszámú ló tehát könnyen megtéveszthette a muszlim szerzők informátorait is. A magyarokkal szomszédos népek adatai szintén megkérdőjelezik a 20 ezres magyar haderő létezését. A központi kazár haderőt Ibn Ruszta

25 VÉKONY 2001. 98-100.

26 Zimonyi 2005. 90-91.

27 Zimonyi 2005. 83-90, MaKkay 1994. 44.

28 Zimonyi 2005. 87.

29 Zimonyi 2005. 87.

30 Moravcsik 1984. 19.

31 MEH 216. 
10 ezer főre tette, később Isztakhri 12 ezer főt említett. ${ }^{32}$ Zimonyi István a központi haderőn kívül számolt a kazár uralom alatt levő katonai segédnépek csapataival is, így 40 ezres összlétszámra következtetett. ${ }^{33}$ Legújabban Szabados György vitatta ezt, és hangsúlyozta, hogy a magyarok központi hadsereglétszáma kétszerese volt a kazárokénak. ${ }^{34} \mathrm{~A}$ volgai bolgárokkal kapcsolatban különböző számadatok állnak rendelkezésünkre. Ibn Fadlán szerint egy törzs össznépessége volt 5 ezer fö Ibn Fadlán szerint. Ezt a Dzsajháni-hagyományban tévesen ötszázezer családként értelmezték. ${ }^{35} \mathrm{Az}$ orosz évkönyvekben ugyanakkor 6 ezer fös bolgár hadakról írnak. ${ }^{36}$ Julianus barát 1236. évi utazásakor azt hallotta, hogy 50 ezer főt tudnak kiállítani. A besenyő haderő száma hasonlóképpen teljességgel bizonytalan. Al Bakri a 11. században 12 ezer muszlim, és 24 ezer pogány besenyőről, azaz 36 ezer fös haderőről tett említést. ${ }^{37}$ Szkülitzész 11. századi bizánci történetíró szerint 1048-ban 11 besenyő kerületben (törzs) 800 ezer besenyő élt. ${ }^{38}$ Ebből Omeljan Pritsak arra következtetett, hogy egy kerület létszáma 72727 fö volt, és egy tüment tudott kiállítani. ${ }^{39}$ Bíborbanszületett Konstantin a 10. század közepén a DAI 37. fejezetében 8 tartományt, themát (törzset) és 40 részt (nemzetséget) említett létszám nélkül. ${ }^{40}$ Utóbbi adatból azt a téves következtetést szűrte le Pritsak, hogy a 40 besenyő rész (kerület) 40 tüment, azaz 400 ezer harcost állított ki, és ebből 2,8-3 milliós lakosságra következtetett. ${ }^{41}$

Maszúdi (Al-Masūdī) a 934-es hadjárat leírásából megtudjuk, hogy a besenyő és magyar közös haderő mozgósítás nélkül volt 60 ezres, mozgósítás esetén 100 ezren lettek volna. ${ }^{42}$ 934-ben tehát még kétszeres besenyő létszámfölénnyel kalkulálva is 30 ezres magyar haderővel számolhatunk. Csakhogy ekkor a magyarság már két néven szerepelt, és ennek oka a honfoglalás kor helyben találtak asszimilációja volt. Saját nézetem szerint a haderő növekménye tőlük származhat, és mivel éppen egy hadjárat kapcsán szerepelnek elődeink két néven, joggal gondolhatjuk, hogy a 30 ezres létszámban már a helyi lakosság is benne volt.

A magyar haderőnek a honfoglalás történetét tárgyalva bemutatott mozgása is megengedi bizonyos következetések levonását annak létszámáról. Konstantin szerint a besenyők a magyarok távollétében azok hátrahagyott családjait, és a földjük őrzésére hátrahagyott magyarokat támadták meg a Kárpátoktól keletre fekvő szállásokon. ${ }^{43}$ Ez a megfogalmazás csak oly módon értelmezhető, hogy a harcképes magyarok döntő többsége távol volt a besenyő támadás idején. Nézetem szerint a Bulgáriában harcolt magyar haderő nem tért haza a keleti szállásokra, hanem Bulgáriát elhagyva Moráviára támadt, majd annak területén áttörve, a Braszláv felügyelte Szlavónián keresztül hatolt be Itáliába. Mind a 895-899 közötti hadjáratsorozat általam feltételezett hosszú időtartama, mind nagyságrendje alapján azt kell feltételeznünk, hogy a magyar haderő zöme részt vett ebben. A forrásaink által igen jelentősnek mondott magyar és bolgár vesztesé-

\footnotetext{
32 Ibn Ruszta isaddal kivonuló 10 ezer lovasára KMoskó 1997. 205.; Isztakhri 12 ezer fös adatára KMosKó 2000. 28.; összefoglalóan Zimonyi 2005. 84.

33 Zimonyi 2005. 85.

34 Szabados 2011. 107-111.

35 Zimonyi 2005. 85.

36 Zimonyi 2005. 86.

37 Kмоsкó 2000. 253.

38 A vonatkozó szakirodalomra vö. ZiMONYI 2005. 86.

39 Pritsak 1975. 226-227; vö. Zimonyi 2005. 86.

40 DAI 2003. 166-167.; Zimonyi 2005. 86, 89.

41 Pritsak 1975. 226-227.; bírálatára vö. Zimonyi 2005. 86.

42 MEH 99.

43 DAI 2003. 176-177.
} 
gek nagyságrendileg megerősíteni látszanak ennek valószínűségét, hiszen a bolgár veszteséget 20 ezer lovasra teszi az Annales Fuldenses. ${ }^{44}$ A magyar veszteség hasonló arányát ugyanakkor megkérdőjelezi a Fuldai Évkönyv megjegyzése az ezek után a két fél között egyre gyakoribbá váló összecsapásokról. ${ }^{45} \mathrm{Az}$ a tény, hogy a magyar-bizánci szövetség megkötésekor mind Árpád, mind Kusal (Kurszán) jelen volt, szintén arra utal, hogy a magyar haderő jelentős részét igénybe vette a bolgárok elleni felvonulás. ${ }^{46}$ Kusal jelenléte azt is jelentheti, hogy a Kárpát-medence keleti részeit 892-894 folyamán megszálló, Kusal vezette magyar hadak részesei lehettek ennek az akciónak. Azonban az a tény, hogy a Bulgáriába vonult magyarokat nem Árpád, nem Kusal, hanem Konstantin császár információja szerint Liüntika, Árpád fia vezette, arra látszik utalni, hogy a Kusal vezette haderőnek csak egy része volt érdekelt, legalábbis a hadjárat bolgár területen zajló szakaszában. ${ }^{47}$

Forrásaink szerint 898/899-900, valamint 901 és 904 során tartózkodott Itáliában magyar haderő, amelyet az első hadjárat idején mintegy 5000 fösre becsült a szakirodalom. ${ }^{48}$ Gombos szerint az Itáliába nyomult, majd Dél-Pannoniát megszállt magyar csoport a nagy erejú és nagy területű itáliai pusztítás alapján igen jelentős létszámú lehetett. ${ }^{49}$ Szerinte azonban a különféle forrásadatok összevetése, és a középkori források ismert túlzásai tekintetbe vétele alapján e magyar csoport létszáma csak 2000 fö lehetett. ${ }^{50}$ Magam azonban többek között éppen Gombos észrevételei következtében az Itáliában járt magyarok létszáma tekintetében inkább pozitív irányban mozdulnák el a sokak által elfogadott 5000 -es létszámtól. ${ }^{51}$ A besenyő támadás szerintem 898 végére tehető időpontja azt sejteti, hogy Konstantin császár az etelközi szállásoktól távol, hadjáraton levő magyarok esetében az Itáliában kalandozó magyarokra gondolhatott. ${ }^{52}$ Figyelemre méltó a Sváb Évkönyvek rövid megjegyzése, mely szerint a brentai csata után a várak elestek, ${ }^{53}$ ami világosan jelzi, hogy a magyaroknak komolyabb erőkkel kellett felvonulniuk. További indítóokunk abban az időbeni egybeesésben áll, amely szerint a 898-904 közötti itáliai magyar hadmozdulatok idején, 900-904 között szinte minden évben balsikerü hadi vállalkozásokra került sor a bajorok ellenében. Bár nem tudjuk, hogy a második és harmadik itáliai hadjártban milyen létszámú magyar sereg vett részt, úgy tünik, távolléte mindegyik esetben komoly gondot okozhatott. Amint azonban hazatért az itáliai sereg, 905-ben már a bajorok súlyos kudarcát jegyezte fel egy forrásunk. Egy év múlva, 906-ban már Szászországig jutottak a magyar hadak, és 907 júliusában döntő vereséget mértek a támadó bajorokra Braslavespurch-nál. ${ }^{54}$

Komoly probléma annak eldöntése, hogy az Itáliából 900-ban visszatérő magyar sereg azonos-e azzal a Kusal vezette magyar haddal, amely ugyanebben az évben betört Noricumba. Az egykorú Fuldai Évkönyvekből úgy tünik, hogy a 899-ben Itáliába tört magyar haderő 900-

\footnotetext{
44 MEH 203.; HKIF 191.

45 MEH 203.; HKÍF 191.

46 A bizánci követ Árpád és Kuszán magyar fejedelmekkel való tárgyalására vö. György barát folytatója, MEH 147.; MORAVCSIK 1984. 59.

47 DAI 2003. 176-177.

48 Két adat kombinációjából (Berengár serege 15 ezres, a magyarok seregénél háromszor nagyobb) következtetett a korábbi történeti kutatás a 899-es magyar kalandozó sereg létszámára (5 ezer fö), PAULER 1900. 36.; TóTH 1998. 168.; Тóтн 2010. 218.

49 Gombos 1927. 456.

50 Gомвоs 1927. 469-470.

51 Pauler 1900. 36.; Tóth 1998. 168.; Tóth 2010. 218.

52 Konstantin információjára a sereg távollétéről (DAI 40. fejezet), DAI 2003. 176-177.

53 HKIF 201.

54 GYöRfFY 1977a. 134-135.; KRISTó 1980. 234-237.; MAKK 1996. 11.; BóNA 2000. 33-35.; TóTH 2010. 55-56.
} 
ban ugyanazon, a bajorok által ellenőrzött úton tért vissza és pusztította el Pannoniát, majd ezek után történt a követküldés Lajoshoz, és Noricum megtámadása. Aventinus szövegéből azonban úgy tűnik, hogy csak a magyarok egy része ment Itáliába, és csak Pannoniának és Noricumnak egy másik magyar csoport által történt megszállása után tért vissza. Szerinte a magyarok Noricum, majd Karintia elpusztítása után, Itáliában Aquileia és Verona vidékét, majd Longobardiát pusztították el, bántatlanul hazatérve, ugyanazon az úton, amelyen oda jutottak..$^{55}$ Ez utóbbi itáliai hadjárat a karintiai betörés 901-es időpontja alapján a 901-ből ismert hadjárattal lehet azonos. Aventinus azonban a Fuldai Évkönyvekből vett „ugyanazon az úton” fordulatot használja, ami arra utal, hogy ő a 899-900-as és 901-es itáliai hadjáratot ugyanazon hadjáratnak tekintette. Aventinus és a Fuldai Évkönyvek is két magyar seregröl tud a 900-as harcok során, amelyek külön-külön támadtak, így esetleg arra gondolhatunk, hogy az itáliai és a pannoniai seregek alkotta önálló hadtestekről lehet szó.

Ekkehard szerint a magyarok óriási sereggel támadtak a Maraviani népre 900-ban. ${ }^{56} \mathrm{Te}$ kintettel arra, hogy a magyarok a Dunától keletre fekvő szállásaikat Észak-Itáliából érkezve leggyorsabban Pannonia Dráva-Száva közötti részén keresztül érhették el, igen valószínű, hogy az Itáliában járt magyar haderő ejtette útba a bajorokkal harcban álló morvák (Nagy Morávia) Száva menti országát. A sereg „óriási” mivolta is e lehetőség mellett szólhat.

Gombos szerint az Itáliában jártakkal szemben az Észak(Nyugat)-Pannoniát megszálló és Noricumot megtámadó magyarok időben és kiterjedésben igen gyenge akciója kis létszámukra utalhat. ${ }^{57}$ Következtetésével csak részben érthetünk egyet. Az Aventinus-kivonat 901-ben Cusa király és előkelői nagy seregéről szól, a Chronicon Salisburgense szerint a 901. évben az ungari-k Bawariaban több mint ezren haltak meg. ${ }^{58}$ Ezek az adatok a 900 -as év második felében lezajlott hadjáratra vonatkozhatnak. A több, mint ezer fös veszteséget szenvedett had a Duna északi partján támadó sereg lehetett, hiszen a déli seregrész visszavonult Pannoniába, egykorú forrásaink nem tudnak velük való ütközetről. A Fuldai Évkönyv híradása alapján ez az északi seregrész lehetett a kisebb létszámú, a velük vívott nagy csata arra utal, hogy a sereg nagy része ott veszett. Az északi seregrész így 1000-2000 fő közé becsülhető. ${ }^{59}$ Kusal seregrésze lehetett a nagyobb létszámú, a hadjárat gyorsasága és a támadás ereje feltételezi ezt. Vélhetően csak az északi sereg megsemmisülése következtében vonult vissza, arról viszont nem tudunk, hogy a bajorok ekkor üldözték volna, erre csak 903-ban kerülhetett sor. Talán e sereg jelentős létszáma, és az Itáliában jártak jelenléte áll a háttérben, hiszen csak 901 folyamán indult újabb hadjárat Itáliába. Szászországban 906-ban szintén két magyar sereg harcolt, és ezek már e hadjárat előtt is külön egységet alkottak. ${ }^{60}$ Ennek az elkülönülésnek talán etnikai háttere (magyar, kavar) is feltételezhető.

Összességében úgy látjuk, a magyar haderő 10 000-20 000 fős összlétszáma nagyságrendjét tekintve mindenképpen jó közelítése a valós helyzetnek. Az a szorzószám, amellyel a kutatók a honfoglaló magyar haderő számát felszorozták a lakosság számának megállapításához, lényegében attól függ, hogy az adott kutató félnomád vagy teljesen nomád életmódúnak fogja fel elődeinket. A nomadizmust számos írott forrás, a félnomád életmódot csupán a kelet-európai

${ }_{55}^{55}$ MEH, 250-251.; HKÍF 274-275.; a 901. évi magyar kalandozásra vö. KRISTó 1980. 231.; MAKK 1996. 10.

${ }^{56}$ Gомвоs II. 865-866.

57 Goмвоs 1927. 458.

${ }^{58}$ Az Aventinus-kivonatra vö. HKÍF 266.

59 A Fuldai Évkönyv 1200-fős magyar veszteséget említett, MEH 204.; HKÍF 192-193.; az északi sereg vereségére KRISTÓ 1980. 212-216.

${ }^{60}$ HKIF 220.; То́тн 2010. 191. 
analógiák, és az Árpád-kori népesség életmódja támasztja alá. Mivel elődeink mindössze fél évszázadot éltek a félnomád kelet-európai népek között, azok életmódját aligha lehet analógiaként felhasználni. A kora Árpád-kori lakosság ismert félnomád, mozgó életmódja pedig a korábbi, késő avar kori népesség életmódjának folytatása is lehet. Kétségtelen tehát, hogy kellő felelősséggel csak a nomádokra jellemző 5-ös, 6-os szorzóval számolhatunk a honfoglaló magyarság összlétszámának becslésekor.

A tümenről fentebb leírtak alapján a honfoglalók két tümennyi hadereje a valóságban 6 ezer és 14 ezer fö között mozoghatott. A honfoglalók döntően nomád életmódja alapján jogosnak látszik az 5-ös vagy 6-os szorzó, bár ennek a kavarokra való alkalmazhatósága bizonytalan, mivel azok vélhetően nem voltak nomádok. Ugyanakkor a jórészt harcra specializálódott kálizokból állt kavar törzsek nagy tömegü közrendü réteggel aligha rendelkezhettek. Ennek alapján - a 6 ezres és 14 ezres tümennel, és 5-ös vagy 6-os szorzóval kalkulálva, reálisan a honfoglalók létszáma lehetett 30 ezer, 36 ezer, 70 ezer vagy akár 84 ezer fó is, sőt a kavarokkal számolva a 100 ezer föt is elérhették.

Bálint Csanád hívta fel arra a figyelmet, hogy az antropológiai leletek tanúsága szerint a kora Árpád-kori népesség 98\%-a nem a honfoglalóktól származott. ${ }^{61} \mathrm{Ez}$ a tény, 1000 körül 1 milliós népességgel számolva azt jelenti, hogy a honfoglalók leszármazottainak létszáma, 1 milliónyi népesség 2\%-a ekkor mintegy 20 ezer fö lehetett, Vékony Gábor eredményeivel összhangban.

Még egy módon ellenőrizhetjük okfejtésünket. A 10. századi klasszikus honfoglaló leletanyagú temetkezések száma mintegy 5000-re tehető. ${ }^{62}$ Mivel teljességgel bizonytalan az első generáció kiválogatása ezek közül, ezért három generációra egyenlően elosztva végzünk egy tájékoztató jellegű számítást. A Vékony által használt módszerrel az egy generációra (33 év) eső 1667 sírból kiindulva 30\%o-es halálozással, 1,56\%-os feltártsági mutatóval 106688 fös honfoglaló népességet kapunk.

Összefoglalóan megállapíthatjuk tehát, hogy a honfoglaló magyarok összlétszáma 30 ezer és 100 ezer fő közötti lehetett. A Vékony által megadott 14 ezres lélekszám legfeljebb a haderő létszámának felelhet meg, a népesség összlétszámát illetően túlzottan alacsonynak látjuk.

\section{SZAKIRODALOM}

BÁlint Csanád (2006): Az ethnosz a kora középkorban. Századok 140. évf. 2. sz. 277-347.

Bartha Antal (1968): A IX-X. századi magyar társadalom. Budapest, Akadémiai Kiadó.

BóNA István (2000): A magyarok és Európa a 9-10. században. História Könyvtár, Monográfiák 12. Budapest, MTA Történettudományi Intézet.

DAI (2003): Bíborbanszületett Konstantin: A birodalom kormányzása. A görög szöveget fordította Moravcsik Gyula. Olajos Terézia bevezető tanulmányával. Budapest (Reprint)

FÜGEDI ERIK (1984): Magyarország népességének fejlődése a középkorban. In Hanák Gábor (szerk.): Gólyavári esték. Elöadások a magyar történelemröl. Budapest. 289-298.

Gombos F. Albin (1927): A honfoglaló magyarok itáliai kalandozása (898-904). Hadtörténelmi Közlemények 40 (1927) 429-519.

Gombos F. Albin (1937-1943): Catalogus Fontium Historiae Hungaricae. I-IV. Budapest.

GYöRFFY GYörgy (1963): Magyarország népessége a honfoglalástól a 14. század közepéig. In Kovacsics József (szerk.): Magyarország történeti demográfiája. Budapest. 45-62.

GYÖRFFY GYöRGY (1977): István király és müve. Budapest, Gondolat.

61 BÁLINT 2006. 346.

62 MaKkAY 1994. 44. táblázat. 
GYörfFy GYÖRGY (1977a): Honfoglalás, megtelepedés és kalandozások. In Bartha Antal - Czeglédy Károly - Róna-Tas András (szerk.): Magyar östörténeti tanulmányok. Budapest, Akadémiai Kiadó. 123-156.

HKÍF (1995): A honfoglalás korának írott forrásai. Olajos Teréz, H. Tóth Imre És Zimonyi István közreműködésével szerkesztette Kristó Gyula. Szegedi Középkortörténeti Könyvtár 7. Szeged, Szegedi Középkorász Mühely.

Kмозкó MıнÁLy (1997): Mohamedán írók a steppe népeiröl. Földrajzi irodalom I/1. Magyar Őstörténeti Könyvtár 10. Budapest, Balassi Kiadó

Kмозкó MiнáLy (2000): Mohamedán írók a steppe népeiről. Földrajzi irodalom I/2. Magyar Őstörténeti Könyvtár 13. Budapest, Balassi Kiadó.

KRISTó Gyula (1980): Levedi törzsszövetségétől Szent István államáig. Budapest, Magvető Könyvkiadó.

Kristó Gyula (1995): Magyarország lélekszáma az Árpád-korban. In Kovacsics József (szerk.): Magyarország történeti demográfiája I. A honfoglalás és az Árpád-kor népessége. Budapest. 42-95.

Kristó Gyula (1996): Magyarország lélekszáma az Árpád-korban. In uő.: Honfoglalás és társadalom. Budapest, MTA Történettudományi Intézet. 110-154.

Makк Ferenc (1996): Magyar külpolitika (896-1196). Szegedi Középkortörténeti Könyvtár 2. Második, bővített és átdolgozott kiadás. Szeged, Szegedi Középkorász Műhely.

MaккаY János (1994): A magyarság keltezése. Bővített kiadás. Szolnok, Damjanich János Múzeum.

MEH (2002): A magyarok elódeiról és a honfoglalásról. Kortársak és krónikások híradásai. Összeállította Györffy György. Budapest, Osiris Kiadó.

MolnáR ERIK (1949): A magyar társadalom története az Árpád-kortól Mohácsig. Budapest, Szikra.

Moór ELEMÉr (1974): A szóegyüttesek és a csoportos szóhiányok: művelődéstörténeti tények. Magyar Nyelv 70. évf. 2. sz. 173-181.

Moravcsik Gyula (1984): Az Árpád-kori magyar történet bizánci forrásai. Budapest, Akadémiai Kiadó.

Pauler Gyula (1899): A magyar nemzet története az Árpádházi királyok alatt. I-II. Budapest. (Reprint, Budapest, 1984.)

PAuler Gyula (1900): A magyar nemzet honalapitása Szent Istvánig. Budapest, MTA.

Pritsak, Omeljan (1975): The Pechenegs. A case of Social and Economic Transformation. Archivum Eurasiae Medii Aevii I. 211-235.

SzABADOS György (2011): Magyarállamalapitások a IX-XI. században. Szegedi Középkortörténeti Könyvtár 26. Szeged, Szegedi Középkorász Mühely.

Tóth SÁNDOR LÁszLó (1988): Az etelközi magyar-besenyő háború. Századok 122. évf. 4. sz. 541-575.

Tóth SÁNDor LÁszLó (1998): Levediától a Kárpát-medencéig. Szegedi Középkortörténeti Könyvtár 14. Szeged, Szegedi Középkorász Mühely.

TóTh SÁNDOR (2010): A honfoglalástól azállamalapításig. A magyarság története aX. században. Budapest, Históriaantik Könyvkiadó.

Zimony István (2005): Muszlim források a honfoglalás elötti magyarokról. A Ğayhānī-hagyomány magyar fejezete. Magyar Östörténeti Könyvtár 22. Budapest, Balassi Kiadó.

Vе́коNY GÁвоR (2001): Népesedési viszonyok az Árpád-korban. In A KSH Népességtudományi Kutatóintézetének 2001. évi történeti demográfiai évkönyve. Budapest. 81-103. 